\title{
The effect of somatotype characters on selected physical performance parameters
}

\author{
Çinarli F.S. ${ }^{\mathrm{ABCDE}}$, Kafkas M.E. ${ }^{\mathrm{ABCD}}$ \\ Department of Movement and Training Science, Inonu University, Malatya, Turkey
}

Authors' Contribution: A - Study design; B - Data collection; C - Statistical analysis; D - Manuscript Preparation; E - Funds Collection.

\begin{abstract}
Purpose: $\quad$ The physical structure is considered as one of the elements for sporting success. The aim of this study was to investigate the effects of somatotype characters on selected physical performance parameters.

Material: $\quad$ This study was included 150 males (age: $22.10 \pm 2.46$ years) participants who do not have habit of regular exercise. The somatotype characters of participants were determined and physical performance tests $(30 \mathrm{~m}$ sprint, vertical jump, anaerobic power, aerobic capacity, and flexibility) were measured as an experimental design.

Results: $\quad$ As a result of the research, 9 different somatotype subgroups were identified. In this study, the statistically significant was found between groups in terms of explosive force, aerobic and anaerobic power output $(p<0.05)$. We found no significant between groups in terms of flexibility $(p=0.670)$, relative anaerobic peak $(p=0.560)$ and mean power output $(p=0.077)$. The results were obtained in favor of mesomorph-endomorph structure in terms of absolute peak and mean power, while mesomorph and ectomorph component contributed positively to explosive force and aerobic capacity scores.

Conclusions: Our study highlighted the fact that the subgroups of somatotype have an effect on performance parameters. The body-performance relationship can be examined in detail with more participants representing each somatotype group.

Keywords: body composition, performance, physical fitness, somatotype components.
\end{abstract}

\section{Introduction}

Exercise planning, ability level and genetic predisposition can be mentioned as the constituent structures of sporting success. In addition, it is possible to emphasize the need for a branch-specific body structure in order to achieve optimal sporting success. Since Sheldon's first studies on somatotypes, many researchers have attempted to determine the effects of somatotype on physical performance $[1,2]$. Somatotype is a taxonomy that allows the interpretation of a body structure based on different elements. Carter and Heath [3] developed a three-dimensional and formula-based concept for the detailed classification of body structure This involves a classification based on 3 components (endomorphmesomorph-ectomorph) and examines the body in detail.

All branches of sport have a unique set of specialized biomotor performance requirements. However, in addition to performance indicators such as strength [4], power [5], flexibility [6], endurance [7] and agility [8] among the factors that have a positive effect on the performance of athletes, physical structure is also considered as one of the elements for high performance [9]. It can be mentioned that the body type of elite or successful athletes competing in a particular sport has features that can provide a template in terms of current performance parameters. For example, while the mesomorph component of elite boxing athletes was noted to be high [10], it was stated that elite wrestlers had mesomorph-endomorph body type [11]. However, it can be seen that within a particular branch of team sport, body types differ depending on the

\footnotetext{
(c) Çinarli F.S., Kafkas M.E., 2019

doi:10.15561/20755279.2019.0602
}

position of the player. Busko et al. [12] found that in the somatotype classification of 14 female volleyball players, the lowest ectomorph and highest endomorph components were found in libero and setters respectively, the highest ectomorphs and lowest endomorphs were found in hitters and opposites respectively. It is considered that the role of somatic elements in the display of the relevant performance parameters can be used for the selection and development of athletes.

This research was based on the 9 groups of the somatotype characters proposed by Carter and Heath. In this context, we believe that the findings as to how the 9 different body types affect motor performance scores may contribute significantly to the literature.

The hypothesis was determined as follows: "somatotype body type differences would affect biomotor performance scores". This study aimed to evaluate the effect of different body types on selected physical test scores.

\section{Material and Methods}

Participants

A total of 150 volunteers, including 150 males participated in the study (age: $22.10 \pm 2.46$ years). All participants were informed about the possible risks and details of the research before beginning the study and were made to sign voluntary consent forms. The study was approved by the Clinical Research Ethics Committee (code:2015/211) and conformed to the Helsinki declaration. The criteria for inclusion in the study were: (a) absence of any health problems in the participants during the performance of the tests, (b) having obtained 
consent from the participants (c) regular participation in all the tests and measurements in the study. The criteria for exclusion from the study were: (a) the occurrence of any health problem, (b) irregularity participation in the measurements, (c) careless behaviors with regard to the optimal execution of performance.

Procedure

Anthropometric measurements and field test protocols were applied to volunteers participating in the study. Participants were told to rest 24 hours before the measurements, away from any heavy physical strain. They were informed a day in advance, that they should not consume stimulants such as tea, coffee, and fizzy drinks. All the measurements and test protocols applied in the study were applied in the faculty of sport sciences physiology laboratory and sports hall. Somatotype measurements were made on all participants in a resting state in the morning after 8 hours of fasting. The participants' motor tests were measured between 09.00 and 11.00. A 5-min general warm-up protocol was applied to the volunteers participating in the study before all tests in order to minimize the risk of disability and to achieve optimal performance.

\section{Somatotype}

All the anthropometric measurements of the subjects were made in accordance with the measurement techniques and standards recommended by the International Society for the Advancement of Kinanthropometry. Carter-Heath [3] method was followed for somatotyping rating as follows:

\section{Endomorphy $=-0.7182+0.1451(\mathrm{X})-0.00068(\mathrm{X})^{2}+$ $0.0000014(\mathrm{X})^{3}$}

Where $\mathrm{X}=$ sum of triceps, subscapular and suprailiac skinfold and for height corrected endomorphy multiplied by 170.18 / body height in $\mathrm{cm}$.

Mesomorphy $=(0.858 \mathrm{x}$ humerus breadth $)+(0.601 \mathrm{x}$ femur breadth $)+(0.188 \times$ corrected arm girth $)+(0.161$ $\mathrm{x}$ corrected calf girth $)-(0.131 \mathrm{x}$ height $)+4.5$

Corrected arm girth: arm girth $(\mathrm{cm})$ - (triseps skinfold / 10) $(\mathrm{mm})$

Corrected calf girth: calf girth - (calf skinfold / 10) (mm)

Ectomorphy $=(0.732 \times$ HWR $)-28.58$

If HWR was found as $38.25<\mathrm{RPI}<40.75$, Ectomorphy $=($ HWR $\times 0.463)-17.63$.

If HWR was found as an equal to or less than 38.25 give a rating of 0.1

HWR: height $(\mathrm{cm}) /$ weight $^{-1 / 3}(\mathrm{~kg})$

In the study, each participant's body height was measured with a stadiometer with a sensitivity level of 0.01 meter $(\mathrm{m})$ and their body weight was measured with an electronic scale (SECA, Germany) with a sensitivity level of 0.1 kilogram $(\mathrm{kg})$. Then body girths (flexed and tensed upper arm girth and calf girth) were measured using flexible but non-stretchable tape (Holtain Ltd, Croswell, UK) to the nearest $0.1 \mathrm{~cm}$. Biepicondylar humeral and femoral breadth were measured using bicondylar caliper (Holtain Ltd, Croswell, UK) to the nearest $0.1 \mathrm{~cm}$. The participants' skinfold thicknesses values were determined with a skinfold caliper (Holtain Ltd, Croswell, UK) from
4 sites (triceps, suprailiac, subscapula, calf).

Field Tests

$30 \mathrm{~m}$ Sprint Test

A "30 m sprint test" was performed to determine the participants' sprint times. Running scores were recorded in seconds using electronic timing gates placed on the start and finish lines (Smart Speed; Fusion Sport, Australia). Passive resting intervals of $3 \mathrm{~min}$ were applied between the repetitions. The test was repeated three times for each participant for the reliability of the test and the best performance score was recorded [13].

Counter Movement Jump (CMJ)

A single vertical jump test was performed to assess the participants' jumping heights. The participants jumped to the highest distance on the floor platform with their knees stretched and hands on their waist in the starting position (Smart Jump; Fusion Sport, Australia). Passive resting intervals of 3 min were applied between the repetitions. The test was repeated three times for each participant for the reliability of the test and the best performance score was recorded [14].

\section{Wingate Anaerobic Test (WANT)}

The participants' body weights were calculated before the test began. Then, the sitting heights were adjusted for each participant, so that there would not be more than 5 degrees of flexion during pedaling. A resistance of 7.5\% of the body weight of each participant was calculated for the Wingate weight basket. A 5-min warm-up period was provided for each participant before the test began. The participants warmed up with 3 repetitions of maximal pedal speed for $5 \mathrm{sec}$. The test lasted for 30 seconds and the participants were verbally encouraged. At the end of 30 seconds the participants were allowed to pedal without weight on the bicycle until their heart rate was about 120 bpm [14]. The parameters obtained as a result of the test which was performed with the Monark 894 E (Sweden) bicycle ergometer connected to a computer and operating with a compatible software were calculated with the software in the computer as anaerobic peak power, anaerobic mean power absolute and relative values.

Maximal Oxygen Consumption (Vo2max)

With the purpose of determining the Vo2max of the participants, the YoYo-1 was used to evaluate people with low fitness levels [15]. The participants were given detailed information about the test procedures and after a routine warm-up the test started. The Vo2max values of the participants were calculated according to the YoYo1 test result using the formula; "Vo2 $\max (\mathrm{mL} / \mathrm{min} / \mathrm{kg})=$ Running distance $(m) * 0.0084+36.4$ ”.

Flexibility Test

The sit and reach test was used to measure flexibility. This test was performed firstly to measure the kneeback tendon flexibility of the participants and secondly to measure the lower back, hip and calf flexibility. Each participant performed 3 repetitions, and only the best one was considered for statistical analysis.

Statistical Analysis

Looking at the "kurtosis and skewness" values (between +1.5 and -1.5 ) and because the number of 
participants was greater than 50, whether the research data were homogeneous or not was tested with the "Kolmogorov Smirnov" test. It was determined in the study that the data showed non-normally distribution. The data were analyzed using the "Kruskal Wallis H", one of the non-parametric tests used for evaluating more than two independent variables. When there was a statistically significant difference between groups, the "MannWhitney U" test was used to find out in which group's favor it was. All statistical analyses were performed with the "IBM SPSS 23" software package. All tests taken were expressed as median (min-max). The level of significance in the study was accepted as $\mathrm{p}<0.05$.

\section{Results}

The measured values somatic and demographic parameters were presented in Table 1 as median (med.), minimum (min.) and maximum (max.) values. The somatochart maps of the participants identified as a result of the research were presented in Figures 1. The identified subtypes were shown in Table 2.

The somatotype values of participants were found as endo (2.8) - meso (4.3) - ecto (2.6) in Table 1. These results showed that 150 male participants had balanced mesomorph body type.

Table 2 shows that 9 different subtypes were identified. The highest variance was found in endomorphic mesomorph body type $(n=44)$. However, the least variance was seen in the mesomorphic endomorph group $(n=7)$.

When Table 3 is examined; there was a significant difference between the groups in terms of vertical jump ( $p$ $=0.015), 30 \mathrm{~m}$ sprint $(\mathrm{p}=0.002)$ and $\mathrm{Vo}_{2} \max (\mathrm{p}=0.000)$.

Table 1. Median and min-max values of the descriptive statistics of the participants $(n=150)$

\begin{tabular}{llll}
\hline Parameters & Median & Min. & Max. \\
\hline Age (year) & 22 & 18 & 34 \\
Body mass index $\left(\mathrm{kg} / \mathrm{m}^{2}\right)$ & 22.2 & 16.5 & 32.6 \\
Body height $(\mathrm{cm})$ & 176 & 160 & 190 \\
Body mass $(\mathrm{kg})$ & 67.6 & 49 & 101 \\
Medial calf skinfold $(\mathrm{mm})$ & 7 & 2 & 18 \\
Triceps skinfold $(\mathrm{mm})$ & 9 & 4 & 22 \\
Subscapular skinfold $(\mathrm{mm})$ & 13 & 7 & 33 \\
Supra-iliac skinfold $(\mathrm{mm})$ & 7 & 3 & 19 \\
Flexed upper arm girth $(\mathrm{cm})$ & 31.7 & 26.5 & 38.5 \\
Medial calf girth $(\mathrm{cm})$ & 36.4 & 29 & 45.5 \\
Bi-Femoral breadth $(\mathrm{cm})$ & 6.5 & 5.6 & 7.9 \\
Bi-Humeral breadth $(\mathrm{cm})$ & 9.3 & 7.5 & 11.8 \\
Endomorphy & 2.8 & 1.3 & 6.9 \\
Mesomorphy & 4.3 & .2 & 7.1 \\
Ectomorphy & 2.6 & .1 & 6.2 \\
\hline
\end{tabular}

Table 2. Determined somatotype body types of participants.

\begin{tabular}{lllll}
\hline Somatotypes & N & ENDO & MESO & ECTO \\
\hline Balanced ectomorph & 16 & 2.39 & 2.21 & 4.88 \\
Balanced mesomorph & 20 & 2.74 & 4.53 & 2.64 \\
Central & 13 & 3.20 & 3.76 & 3.07 \\
Ectomorphic mesomorph & 9 & 1.97 & 4.87 & 3.18 \\
Endomorphic mesomorph & 44 & 3.49 & 5.15 & 1.83 \\
Mesomorph-ectomorph & 13 & 2.11 & 3.69 & 3.60 \\
Mesomorph-endomorph & 13 & 4.54 & 4.74 & 1.81 \\
Mesomorphic ectomorph & 15 & 1.98 & 3.38 & 4.47 \\
Mesomorphic endomorph & 7 & 4.93 & 3.73 & 2.24 \\
\hline
\end{tabular}


Table 3. Median and min-max values of field performance tests and Kruskal Wallis $\mathrm{H}$ test results of somatotype

\begin{tabular}{|c|c|c|c|c|c|c|c|c|}
\hline \multirow{2}{*}{ Somatotype } & \multicolumn{2}{|l|}{$\begin{array}{l}\text { VJ } \\
(\mathrm{cm})\end{array}$} & \multicolumn{2}{|c|}{$30 \mathrm{~m}$ sprint (sec) } & \multicolumn{2}{|c|}{$\begin{array}{l}\text { Flexibility } \\
\text { (cm) }\end{array}$} & \multicolumn{2}{|c|}{$\begin{array}{l}\text { Vo2max } \\
\mathrm{ml} / \mathrm{kg} / \mathrm{min}\end{array}$} \\
\hline & Med. & Min-max & Med. & $\begin{array}{l}\text { Min- } \\
\max \end{array}$ & Med. & Min-max & Med. & Min-max \\
\hline \multirow{2}{*}{ Balanced ectomorph } & \multirow{2}{*}{36.8} & 32.4 & \multirow{2}{*}{3.9} & 3.8 & \multirow{2}{*}{30.5} & 19 & \multirow{2}{*}{47.4} & 43.7 \\
\hline & & 46.5 & & 4.1 & & 43 & & 58.2 \\
\hline \multirow{2}{*}{ Balanced mesomorph } & \multirow{2}{*}{35.9} & 26.9 & \multirow{2}{*}{3.9} & 3.8 & \multirow{2}{*}{29.6} & 12 & \multirow{2}{*}{49.8} & 45.8 \\
\hline & & 53.5 & & 4.5 & & 47 & & 62.9 \\
\hline \multirow{2}{*}{ Central } & \multirow{2}{*}{34.3} & 29.8 & \multirow{2}{*}{4} & 3.8 & \multirow{2}{*}{29} & 16 & \multirow{2}{*}{48.8} & 43.4 \\
\hline & & 44.7 & & 4.2 & & 35 & & 57.5 \\
\hline \multirow{2}{*}{$\begin{array}{l}\text { Ectomorphic } \\
\text { mesomorph }\end{array}$} & \multirow{2}{*}{41.3} & 30.5 & \multirow{2}{*}{3.8} & 3.6 & \multirow{2}{*}{26} & 10 & \multirow{2}{*}{53.8} & 46.4 \\
\hline & & 54.3 & & 4.1 & & 40 & & 64.2 \\
\hline \multirow{2}{*}{$\begin{array}{l}\text { Endomorphic } \\
\text { mesomorph }\end{array}$} & \multirow{2}{*}{35.2} & 20.6 & \multirow{2}{*}{3} & 3.7 & \multirow{2}{*}{34} & 13 & \multirow{2}{*}{49.6} & 39.7 \\
\hline & & 64.4 & & 4.6 & & 48 & & 63.9 \\
\hline \multirow{2}{*}{$\begin{array}{l}\text { Mesomorph- } \\
\text { ectomorph }\end{array}$} & \multirow{2}{*}{38.7} & 28.9 & \multirow{2}{*}{3.9} & 3.6 & 31 & 21 & 515 & 43.4 \\
\hline & & 52.1 & & 4.2 & נI & 42 & כ.+J & 60.9 \\
\hline Mesomorph- & 317 & 27.5 & 41 & 3.8 & 35 & 22.1 & 118 & 42.4 \\
\hline endomorph & נI. & 44.4 & 4.1 & 4.3 & כנד & 42 & 44.0 & 50.8 \\
\hline Mesomorphic & 352 & 29.6 & 4 & 3.7 & 29 & 15 & 505 & 43.4 \\
\hline ectomorph & 35.2 & 41.5 & 4 & 4.2 & 29 & 39 & 50.5 & 63.6 \\
\hline Mesomorphic & 33 & 28.3 & 42 & 3.9 & 37 & 17 & 164 & 42.4 \\
\hline endomorph & כנ & 42.1 & 4.2 & 4.3 & 32 & 42 & 40.4 & 50.1 \\
\hline $\mathrm{X}^{2}$ & 19.056 & & 24.217 & & 5.801 & & 28.726 & \\
\hline df & 8 & & 8 & & 8 & & 8 & \\
\hline $\mathrm{p}$ value & $p=0.015^{*}$ & & $p=0.00$ & & $p=0.670$ & & $p=0.00$ & \\
\hline
\end{tabular}

${ }^{*}=p<0.05 ; \mathrm{VJ}=$ Vertical jump; Vo2max = Maximum oxygen capacity; P value was calculated by Kruskal-Wallis Test

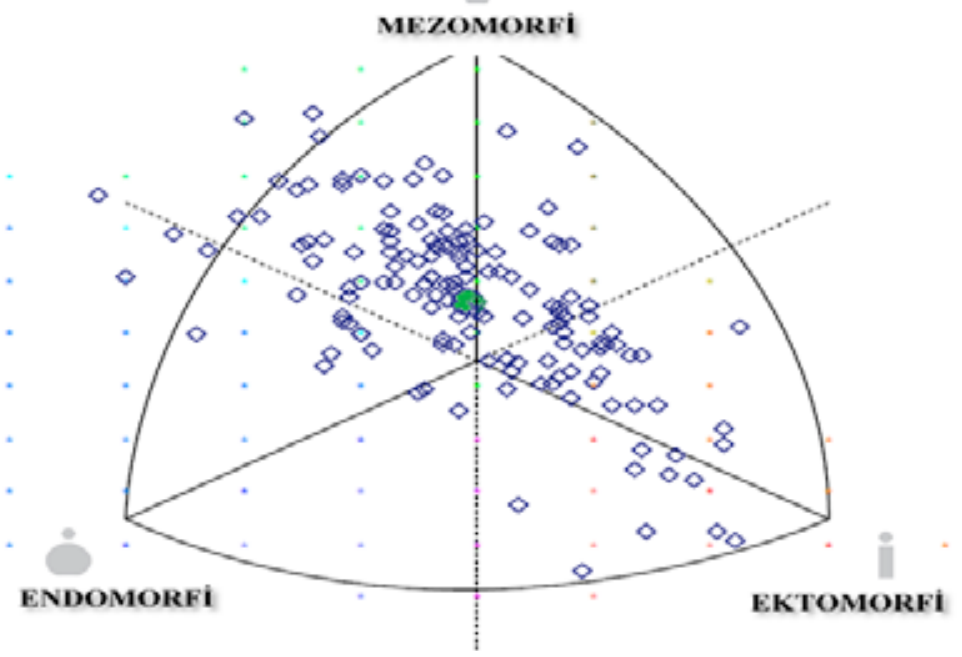

Figure 1- Individual somatoplots of participants and the mean somatoplot for all participants (circle). 
Table 4 shows the difference between the body types. No correlation was found between flexibility and somatotype $(\mathrm{p}=0.670)$.

There was a significant difference between the groups in terms of anaerobic power jump $(p=0.019)$, anaerobic capacity $(\mathrm{p}=0.018)$ in Table 5 . Table 6 shows the difference between the body types. No correlation was found between relative values and somatotype $(p>0.05)$.

\section{Discussion}

The results of the study showed that somatotype body types have an important effect on the range of performance scores. It was seen that the mesomorphic character has a positive effect on sprint performance scores, while the endomorphic character has a negative effect on vertical jump scores. In addition, the mesomorphic and ectomorphic character has a positive effect on aerobic capacity. Also, it was found that those with a center type obtained the highest performance score in terms of anaerobic power values, while those with a mesomorphic ectomorph character showed the lowest performance scores. These findings reveal the importance of the morphological structure and anthropometric elements that significantly affect motor performance scores including power, strength, speed and endurance.

The average somatotype scores of the participants indicated a balanced mesomorph structure (2.8-4.32.6). As a rational explanation of this situation, it is known that even though the participants in the research group did not do sports at a professional level, they had a sports background, because they were students of the sport science faculty. It can be suggested that a dominant

Table 4. Mann-Whitney $U$ test results of body types and performance tests with significant differences

\begin{tabular}{|c|c|c|c|c|}
\hline Parameters & $\mathbf{U}$ & $\mathbf{Z}$ & $\mathbf{p}$ & Somatotypes \\
\hline & 45.000 & -2.588 & 0.010 & $1>7$ \\
\hline & 22.000 & -2.273 & 0.023 & $1>9$ \\
\hline & 28.500 & -2.004 & 0.045 & $3<4$ \\
\hline Vertical & 91.500 & -2.523 & 0.012 & $4>5$ \\
\hline \multirow[t]{11}{*}{ jump } & 17.500 & -2.739 & 0.006 & $4>7$ \\
\hline & 28.500 & -2.327 & 0.020 & $4>8$ \\
\hline & 12.000 & -2.064 & 0.039 & $4>9$ \\
\hline & 38.000 & -2.385 & 0.017 & $6>7$ \\
\hline & 33.500 & -2.184 & 0.029 & $1>4$ \\
\hline & 15.000 & -2.745 & 0.006 & $1<9$ \\
\hline & 45.000 & -2.123 & 0.034 & $2>4$ \\
\hline & 27.000 & -2.382 & 0.017 & $2<9$ \\
\hline & 23.000 & -2.372 & 0.018 & $3>4$ \\
\hline & 41.500 & -2.207 & 0.027 & $3>6$ \\
\hline & 19.000 & -2.101 & 0.037 & $3<9$ \\
\hline \multirow{15}{*}{$30 \mathrm{~m}$ sprint } & 93.500 & -2.486 & 0.013 & $4>5$ \\
\hline & 14.000 & -2.973 & 0.003 & $4<7$ \\
\hline & 33.000 & -2.059 & 0.040 & $4<8$ \\
\hline & 48.000 & -3.030 & 0.002 & $4<9$ \\
\hline & 175.000 & -2.103 & 0.035 & $5<6$ \\
\hline & 62.000 & -2.520 & 0.012 & $5<9$ \\
\hline & 29.500 & -2.823 & 0.005 & $6<7$ \\
\hline & 6.500 & -3.095 & 0.002 & $6<9$ \\
\hline & 16.500 & -2.540 & 0.009 & $8<9$ \\
\hline & 80.500 & -2.538 & 0.011 & $1<2$ \\
\hline & 28.500 & -2.465 & 0.014 & $1<4$ \\
\hline & 55.000 & -2.151 & 0.031 & $1>7$ \\
\hline & 27.500 & -3.786 & 0.000 & $2>7$ \\
\hline & 17.000 & -2.944 & 0.003 & $2>9$ \\
\hline & 26.500 & -2.141 & 0.032 & $3<4$ \\
\hline \multirow{9}{*}{$\begin{array}{l}\text { Maximum oxygen } \\
\text { capacity }\end{array}$} & 40.000 & -2.286 & 0.022 & $3>7$ \\
\hline & 8.000 & -3.376 & 0.001 & $4>7$ \\
\hline & 5.500 & -2.764 & 0.006 & $4>9$ \\
\hline & 114.000 & -3.274 & 0.001 & $5>7$ \\
\hline & 65.000 & -2.439 & 0.015 & $5>9$ \\
\hline & 29.000 & -2.852 & 0.004 & $6>7$ \\
\hline & 20.000 & -2.028 & 0.043 & $6>9$ \\
\hline & 32.000 & -3.022 & 0.003 & $7<8$ \\
\hline & 21.500 & -2.190 & 0.026 & $8>9$ \\
\hline
\end{tabular}

(1) Balanced ectomorph; (2) Balanced mesomorph; (3) Central (4) Ectomorphic mesomorph (5) Ectomorphic mesomorph; (6) Mesomorph-ectomorph; (7) Mesomorph-endomorph; (8) Mesomorphic ectomorph; (9) Mesomorphic endomorph. P value was calculated by Mann-Whitney U test 
Table 5. Median and minimum-maximum values of Wingate Test and Kruskal Wallis $\mathrm{H}$ test results of somatotype

\begin{tabular}{|c|c|c|c|c|c|c|c|c|}
\hline \multirow[t]{2}{*}{ Somatotype } & \multicolumn{2}{|l|}{$\begin{array}{l}\text { Wingate } \\
\text { Peak }\end{array}$} & \multicolumn{2}{|l|}{$\begin{array}{l}\text { Wingate } \\
\text { Mean }\end{array}$} & \multicolumn{2}{|c|}{$\begin{array}{l}\text { Wingate } \\
\text { Relative Peak }\end{array}$} & \multicolumn{2}{|c|}{$\begin{array}{l}\text { Wingate } \\
\text { Relative Mean }\end{array}$} \\
\hline & Med. & $\begin{array}{l}\text { Min- } \\
\max \end{array}$ & Med. & $\begin{array}{l}\text { Min- } \\
\max \end{array}$ & Median & $\begin{array}{l}\text { Min- } \\
\max \end{array}$ & Median & $\begin{array}{l}\text { Min- } \\
\max \end{array}$ \\
\hline \multirow{2}{*}{ Balanced ectomorph } & \multirow{2}{*}{630.1} & 428.3 & \multirow{2}{*}{437.1} & 336.6 & \multirow{2}{*}{9} & 7.1 & \multirow{2}{*}{6.8} & 5.8 \\
\hline & & 784.6 & & 533.1 & & 12.1 & & 7.9 \\
\hline \multirow{2}{*}{ Balanced mesomorph } & \multirow{2}{*}{664.5} & 439.6 & \multirow{2}{*}{467.2} & 338.6 & \multirow{2}{*}{9.7} & 7.4 & \multirow{2}{*}{7} & 5.5 \\
\hline & & 891.2 & & 598.5 & & 11.3 & & 8.1 \\
\hline \multirow{2}{*}{ Central } & \multirow{2}{*}{698.6} & 564.3 & \multirow{2}{*}{503.9} & 293 & \multirow{2}{*}{10} & 8.6 & \multirow{2}{*}{6.9} & 4.5 \\
\hline & & 872.2 & & 578 & & 11.5 & & 7.8 \\
\hline \multirow{2}{*}{$\begin{array}{l}\text { Ectomorphic } \\
\text { mesomorph }\end{array}$} & \multirow{2}{*}{656} & 552.3 & \multirow{2}{*}{461.5} & 444.9 & \multirow{2}{*}{10} & 8.9 & \multirow{2}{*}{7.2} & 6.5 \\
\hline & & 825.7 & & 534.1 & & 12.3 & & 7.9 \\
\hline \multirow{2}{*}{$\begin{array}{l}\text { Endomorphic } \\
\text { mesomorph }\end{array}$} & \multirow{2}{*}{692.5} & 494.7 & \multirow{2}{*}{490.5} & 386 & \multirow{2}{*}{9.7} & 6.5 & \multirow{2}{*}{6.8} & 4.6 \\
\hline & & 1013 & & 651.1 & & 12.1 & & 7.8 \\
\hline \multirow{2}{*}{ Mesomorph-ectomorph } & \multirow{2}{*}{656.8} & 591.6 & \multirow{2}{*}{481.3} & 423.4 & 107 & 8.8 & 73 & 6.3 \\
\hline & & 871.8 & & 569.9 & & 12.4 & 1.3 & 8.3 \\
\hline Mesomornh-endomornh & 7479 & 551.7 & 5125 & 378 & 102 & 7.3 & 67 & 5 \\
\hline & & 954.9 & & 613.8 & 10.2 & 12 & 0.1 & 7.7 \\
\hline Mesomorphic & 5989 & 390.7 & 4237 & 272.1 & 104 & 7.1 & 68 & 4.9 \\
\hline ectomorph & 598.9 & 790.8 & $4 \angle 3.1$ & 549.6 & 10.4 & 11.5 & 0.8 & 7.8 \\
\hline Mesomorphic & 730 & 488 & 2 & 358.6 & 0 & 7.1 & 6 & 5.2 \\
\hline endomorph & 139 & 911.7 & 494.2 & 583.3 & 9.6 & 11.4 & 6.6 & 7.5 \\
\hline$X^{2}$ & 18.365 & & 18.398 & & 6.787 & & 14.171 & \\
\hline$d f$ & 8 & & 8 & & 8 & & 8 & \\
\hline$p$ value & $p=0.019 *$ & & $p=0.018^{*}$ & & $p=0.560$ & & $p=0.077$ & \\
\hline
\end{tabular}

$*=p<0.05 ;$ P value was calculated by Kruskal-Wallis Test

Table 6. Mann-Whitney $U$ test results of body types and performance tests with significant differences

\begin{tabular}{lllll}
\hline Parameters & $\mathbf{U}$ & $\mathbf{Z}$ & $\mathbf{p}$ & Somatotypes \\
\hline & 51.000 & -2.324 & 0.020 & $1<3$ \\
Wingate & 184.000 & -2.808 & 0.005 & $1<5$ \\
Peak & 43.000 & -2.675 & 0.007 & $1<7$ \\
Power & 26.000 & -2.004 & 0.045 & $1<9$ \\
& 51.500 & -2.119 & 0.033 & $3>8$ \\
& 184.000 & -2.542 & 0.011 & $5>8$ \\
& 43.000 & -2.280 & 0.023 & $6>8$ \\
Wingate & 40.000 & -2.649 & 0.008 & $7>8$ \\
Mean & 181.000 & -2.859 & 0.004 & $1<5$ \\
Power & 55.000 & -2.149 & 0.032 & $1<6$ \\
& 50.000 & -2.368 & 0.018 & $1<7$ \\
& 84.000 & -2.200 & 0.028 & $2>8$ \\
& 50.000 & -2.188 & 0.029 & $3>8$ \\
& 151.000 & -3.116 & 0.002 & $5>8$ \\
& 45.000 & -2.418 & 0.016 & $6>8$ \\
& 40.000 & -2.649 & 0.008 & $7>8$ \\
\hline
\end{tabular}

(1) Balanced ectomorph; (2) Balanced mesomorph; (3) Central (4) Ectomorphic mesomorph (5) Ectomorphic mesomorph; (6) Mesomorph-ectomorph; (7) Mesomorph-endomorph; (8) Mesomorphic ectomorph; (9) Mesomorphic endomorph. P value was calculated by Mann-Whitney U Test 
mesomorph character was detected for this reason. In research into the somatotype body types of similar age groups, Gualdi and Graziani [16] determined the somatotype scores of 717 male young sports participants and found them to be 2.7-4.7-2.7 for males. Similarly, Gasparini [17] found that the mesomorph character of 19 football players (mean age $=18.8$ years) was greater than the other two components (2.9-4.5-2.9).

In this study, which used the 9 different body type classification proposed by Carter and Heath, statistically significant differences were found between the groups in terms of $30 \mathrm{~m}$ sprint and vertical jump performance. In this study, endomorphic mesomorph participants (3.4-5.1-1.8) scored best in terms of the $30 \mathrm{~m}$ sprint. In the literature, the results obtained in many studies where linear speed is important do not differ from this. Gontarev et al. [18] examined 5 different age groups in football players, and stated that the dominant component was mesomorph. Arjunan [19] examined the somatotype classification of 15 male $100 \mathrm{~m}$ and $200 \mathrm{~m}$ sprinters and found that the athletes had a dominant mesomorphic character (3.4-5.5-4.1). According to Marta et al. [20] mesomorphy may have a significant positive influence on sprint running gains, and the ectomorphic component may be positively associated with sprint running gains. A study found that somatotype rate influences the running time to $30.4 \%$ and also that the endomorphy rate was said to make a substantial contribution to the regression of the run split time [21]. In terms of vertical jumping, the best performance was obtained by the participants of the ectomorphic mesomorph (1.9-4.8-3.1). Pastore et al. [22] stated that beach volleyball players under the age of 19 and 21 who competed in the European championship were mesomorph-ectomorph. It can be said that the endomorphic component, which is an indicator of fatness on the part of athletes, may have a negative effect in the case of beach volleyball, where the jump performance on difficult ground is exhibited. Moss et al. [23] reported that counter movement jump height was also negativelyaffected by higher body fat values. Busko et al. [12] found that there was a significant negative correlation between the rate of elevation of the center of body mass and the endomorphic component $(\mathrm{r}=-0.59)$. In the light of the findings obtained in this study, it can be said that the dominant mesomorph component in terms of $30 \mathrm{~m}$ sprint and the mesomorph-ectomorph component in terms of vertical jumping contribute positively to the performance results.

There was no significant difference between the groups in terms of flexibility performance and somatotype component $(\mathrm{p}=0.670)$. In the literature, there are studies indicating that there is no relationship between hamstring flexibility and somatotype component [24]. Singh et al. [25] found a negative relationship between endomorph and flexibility in 8-year-old children, and in the same study found a significant positive relationship between endomorph and flexibility in 9-year-old children. This suggests that somatotype elements may cause inconsistent findings in terms of flexibility performance.
One of the reliable parameters in determining the sporting performance and the exercise levels of individuals is maximal oxygen capacity. In a study examining the effect of the somatotype character on ventilatory threshold and vVo2max values - the determinants of aerobic capacity - those participants (mean age: 21.4 years) with a mesomorph-ectomorph and mesomorph body type were found to have the greatest improvements scores in terms of aerobic capacity [26]. In a further study it was reported that the greatest gains in aerobic fitness were for individuals with ectomorphic dominance (odds ratio, 3.84; 95\% CI, 1.20-12.27) [20]. In this study, a significant difference was found between the groups according to the results with regard to maximal oxygen capacity $(\mathrm{p}=0.000)$. The highest scoring group was ectomorphic mesomorph $(53.8 \mathrm{ml} / \mathrm{kg} / \mathrm{min})$, while the lowest scoring group was mesomorph endomorph (44.8 $\mathrm{ml} / \mathrm{kg} / \mathrm{min})$. Sinırkavak et al. [27] found that there was a significant negative correlation between maximal oxygen consumption and body fat ratio per kilogram in women $(r=-0.92)$, men $(r=-0.52)$ and regardless of gender $(r=-0.62)$. These findings show that mesomorph and ectomorph components make a positive contribution to performance in terms of aerobic capacity, but there may also be a negative correlation between endomorph score and Vo2max.

Peak power and mean power scores were significantly different between somatotype components $(p=0.019 ; p=$ 0.018 , respectively). The highest score in terms of both peak power (747.9 watts) and mean power (512.5 watts) was shown by the mesomorph-endomorph participants. When absolute peak power output scores are examined, Sanchez-Puccini et al. [28] found a 591.9 \pm 91.0 watt PP score in the case of elite male karate athletes who had a mesomorph-endomorph somatotype character. Also, Ramirez et al. [11] reported a 602.5 \pm 89.3 watt PP score in the case of elite male wrestlers who had a mesomorphendomorph somatotype character. Lewandovska et al. [29] examined the maximal muscle torques of the elbow, shoulder, hip, knee and trunk flexor-extensors of 13 judo athletes identified as endomorphic mesomorph. They found a significant positive correlation between the power outputs of all regions and the mesomorph component, together with a negative correlation between the power outputs of all regions and ectomorph components. Quarria and Wilson [30] found that rugby players with more endomesomorphic structures produce higher scrumming forces than ectomorphic athletes. The body fat and therefore the endomorph and mesomorph components can be said to have a positive effect on achieving peak power output.

\section{Acknowledgements}

This study was written by abridging Fahri Safa ÇINARLI's İnönü University Institute of Health Sciences, Physical Training and Sports Department master's thesis. We would like to thank students who participated in the study and Inonu University Scientific Research Projects Coordination Unit that provided financial support with the project number $2016 / 31$ for the purchase of materials 
used in the research.

\section{Conclusion}

According to the findings obtained from this study, somatotype body types have a significant role to play in terms of motor performance scores. In general, when explosive force and Vo2max scores are examined, it can be said that meso-ecto components can contribute positively to performance scores. When power output scores are examined, it can be said that meso-endo components can contribute positively to performance scores. It is thought that the relationship between basic sport performance skills and somatotype components may act as a selection and guidance tool for athletes in lower age groups.

\section{Conflicts of Interest}

The authors declare no conflict of interest.

\section{References}

1. Kutáč P. Somatic parameters of 17 year old soccer players in the older youth category in relation to sports performance. Acta Gymnica. 2013;43(3):17- 26. https://doi.org/10.5507/ag.2013.014

2. Nikolaidis PT, Afonso J, Busko K. Differences in anthropometry, somatotype, body composition and physiological characteristics of female volleyball players by competitionlevel.SportSciencesforHealth.2015;11(1):29-35. https://doi.org/10.1007/s11332-014-0196-7

3. Carter JEL, Heath BI. Somatotyping. Development and Applications. Cambridge, UK: Cambridge University Press; 1990.

4. Ostojic SM, Mazic S, Dikic N. Profiling in basketball: physical and physiological characteristics of elite players. Journal of Strength and Conditioning Research. 2006;20(4):740-744. https://doi.org/101519/00124278-200611000-00003

5. Bale P, Colley E, Mayhew JL, Piper FC, Ware JS. Anthropometric and somatotype variables related to strength in American football players. The Journal of Sports Medicine and Physical Fitness. 1994;34(4):383-389.

6. Ahvazi SP, Sadeghi H, Gholami M. The effect of eight weeks of flexibility training on step length, range of motion, and balance of middle-aged men and women with ectomorph and endomorph body types. European Journal of Experimental Biology. 2014;4(1):278-282.

7. Salimi HR, Heidari N, Salimi A. The relation between somatotype with aerobic capacity and balance in the boys 1113 years. Turkish Journal of Kinesiology. 2016;2(2):23-26. https://doi.org/10.1007/s12182-016-0080-y

8. Jakovljevic S, Karalejic M, Pajic Z, Gardasevic B, Mandic R. Influence of anthropometric characteristics on speed abilities of 14 years old elite male basketball players. Journal of Physical Education and Sport. 2011;11(2):221-225.

9. Saha S. Somatotype, body composition and explosive power of athlete and non-athlete. Archives of Exercise in Health and Disease. 2015;5(1):354-358. https://doi.org/ 10.5628/aehd.v5i1-2.174

10.Noh JW, Kim JH, Kim J. Somatotype analysis of Korean wrestling athletes compared with nonathletes for sports health sciences. Toxicology and Environmental Health Sciences. 2013;5(3):163-168. https://doi.org/ 10.1007/s13530-013-0170-9

11.Ramirez-Velez R, Argothyd R, Meneses-EchavezJF, SanchezPuccini MB, Lopez-Alban CA, Cohen DD. Anthropometric characteristics and physical performance of colombian elite malewrestlers.Asianjournalofsportsmedicine. 2014;5(4):1-4. https://doi.org/10.5812/asjsm.23810

12.Busko K, Lewandowska J, Lipińska M, Michalski R, Pastuszak A. Somatotype-variables related to muscle torque and power output in female volleyball players. Acta of Bioengineering and Biomechanics. 2013;15(2):119-126. https://doi.org/10.5277/abb130214

13.Hopkins WG. Measures of reliability in sports medicine

and science. Sports Medicine. 2000;30(1):1-15. https://doi.org/10.2165/00007256-200030010-00001

14. Santos EL, Novaes JS, Reis VM, GiannellaNeto A. Low sampling rates bias outcomes from the Wingate test. International Journal of Sports Medicine. 2010;31(11):784-789. https://doi.org/10.1055/s-0030-1262875

15.Bangsbo J, Iaia FM, Krustrup P. The Yo-Yo intermittent recovery test. Sports Medicine. 2008;38(1):37-51. https://doi.org/10.2165/00007256-200838010-00004

16.Gualdi-Russo E, Graziani I. Anthropometric somatotype of Italian sport participants. The Journal of Sports Medicine and Physical Fitness. 1993;33(3):282-291.

17.Gasparini S. The major role of physical and morphological features in competition success. Journal of Administrative Management, Education and Training. 2016;12(3):234-236.

18.Gontarev S, Kalac R, Zivkovic V, Ameti V, Redjepi A. Anthropometrical Characteristics and Somatotype of Young Macedonian Soccer Players. International Journal of Morphology. 2016;34(1):160-167. https://doi.org/10.4067/S0717-95022016000100024

19.Arjunan R. An analysis of somatotype characteristics of college level sprinters. Indian Journal of applied research. 2015;5(11):58-59.

20.Marta CC, Marinho DA, Barbosa TM, Carneiro AL, Izquierdo M, Marques MC. Effects of body fat and dominant somatotype on explosive strength and aerobic capacity trainability in prepubescent children. The Journal of Strength \& Conditioning Research. 2013;27(12):3233-3244. https://doi.org/10.1519/JSC.0000000000000252

21.Kandel M, Baeyens JP, Clarys P. Somatotype, training and performance in Ironman athletes. European Journal of Sport Science. 2014;14(4):301-308. https://doi.org/ 10.1080/17461391.2013.813971

22.de Faria Pastore JC, de Azevedo Ferreira CA, da Costa FCH, João PV. Kinanthropometric Profile of Beach Volleyball Player of Category under 19 and under 21 of European Championship. International Journal of Sports and Physical Education. 2016;2(2):20-24. https://doi.org/10.20431/2454-6380.0202010

23.Moss SL, McWhannell N, Michalsik LB, Twist C. Anthropometric and physical performance characteristics of top-elite, elite and non-elite youth female team handball players. Journal of Sports Sciences. 2015;33(17): 1780-1789. https://doi.org/10.1080/02640414.2015.1012099

24.Alkandari JR, Nieto MB. Somatotype Components, Aerobic Fitness and Grip Strength in Kuwaiti Males and Females. Health. 2016;8(13):1349-1355. https://doi.org/ 10.4236/health.2016.813135

25.Singh AK, Elayaraja M, Jaiswal A. Somatotyping and Biomotor Features of Male Children of Chandauli and Mirzapur Districts of Uttar Pradesh, India. American Journal of Sports Science. 2016;4(1-1):9-14. https://doi.org/ 10.11648/j.ajss.s.2016040101.12 
26.Chaouachi M, Chaouachi A, Chamari K, Chtara M, Feki Y, Amri M, Trudeau F. Effects of dominant somatotype on aerobic capacity trainability. British Journal of Sports Medicine. 2005;39(12):954-959. https://doi.org/10.1136/bjsm.2005.019943

27.Sınırkavak G, Uğur D, Çetinkaya Ö. The Relation between the body composition and maximal oxygen capacity in elite sportsmen. Faculty of Medicine Journal. 2004;6(4):171-176.

28.Sánchez-Puccini MB, Argothy-Bucheli RE, MenesesEchávez JF, López-Albán CA, Ramírez-Vélez R. Anthropometric and physical fitness characterization of male elite karate athletes. Int. J. Morphol. 2014;32(3):1026-31. https://doi.org/10.4067/S0717-95022014000300045

29.Lewandowska J, Buśko K, Pastuszak A, Boguszewska K. Somatotype variables related to muscle torque and power in judoists. Journal of human kinetics. 2011;30:21-28. https://doi.org/10.2478/v10078-011-0069-y

30.Quarrie KL, Wilson BD. Force production in the rugby union scrum. Journal of Sport Science. 2000;8(4):237-246. https://doi.org/10.1080/026404100364974

\section{Information about the authors:}

Çinarli F.S. (Corresponding author); http://orcid.org/0000-0002-7552-367X; safa.cinarli@gmail.com; Department of Movement and Training Science, Inonu University ; Malatya, Turkey.

Kafkas M.E.; http://orcid.org/0000-0002-3962-6428; mkafkas1983@gmail.com; Department of Movement and Training Science, Inonu University ; Malatya, Turkey.

\section{Cite this article as:}

Çinarli FS, Kafkas ME. The effect of somatotype characters on selected physical performance parameters. Physical education of students, 2019;23(6):279-287.

https://doi.org/10.15561/20755279.2019.0602

This is an Open Access article distributed under the terms of the Creative Commons Attribution License, which permits unrestricted use, distribution, and reproduction in any medium, provided the original work is properly cited http://creativecommons.org/licenses/by/4.0/deed.en

Received: 26.10 .2019

Accepted: 17.11.2019; Published: 18.12 .2019 